\title{
PENGALAMAN DAYA TAHAN DIRI PELAJAR UNIVERSITI: KEPERLUAN KEPADA PENYESUAIAN KEHIDUPAN DI KAMPUS
}

\section{(UNIVERSITY STUDENTS' RESILIENCE EXPERIENCE: THE NEED FOR ON-CAMPUS LIFE ADJUSTMENT)}

\author{
Nor Ezdianie Omar ${ }^{1 *}$ and Muhamad Noh Abdullah² \\ ${ }^{1}$ Faculty of Business, Economics and Social Development, \\ Universiti Malaysia Terengganu, 21030 Kuala Nerus, Terengganu, Malaysia \\ ${ }^{2}$ Lembaga Penduduk dan Pembangunan Keluarga Negara, \\ Pejabat LPPKN Negeri Terengganu, No 21, Tingkat 1\& 2, \\ Pusat Niaga Paya Keladi, 20100 Kuala Terengganu, Terengganu, Malaysia \\ *Corresponding author: ezdianie@umt.edu.my
}

Publication date: 23 December 2020

To cite this article: Nor Ezdianie Omar, \& Muhamad Noh Abdullah. (2020). Pengalaman daya tahan diri pelajar universiti: Keperluan kepada penyesuaian kehidupan di kampus. Asia Pacific Journal of Educators and Education, 35(2), 109-129. https://doi.org/10 .21315/apjee2020.35.2.7

To link to this article: https://doi.org/10.21315/apjee2020.35.2.7

\begin{abstract}
The low level of resilience had disrupted the psychological well-being and sustainable education of students who studied in the field of helping profession, at two distinct public universities in Terengganu. Therefore, the present study explored the students' resilience via the qualitative method. The data was collected vis-à-vis focus group interviews based on a semi-structured interview protocol. In general, 16 students participated in the study. They pursued a Diploma in Nursing, Radiography, a Bachelor of Medicine and Surgery and a Bachelor of Counselling at Universiti Malaysia Terengganu and Universiti Sultan Zainal Abidin. These informants were selected via stratified purposive sampling, and the obtained data were analysed thematically. Results revealed that the informants learned ways to build resilience and how the power of resilience helped their adaptability skills in university. In conclusion, the present study contributed to the knowledge of resilience, which reinforced these students' resilience. Finally, the present study recommended web-based intervention to promote and enhance students' resilience in tertiary education.
\end{abstract}

Keywords: Resilience, Terengganu, helping profession, campus life

(C) Penerbit Universiti Sains Malaysia, 2020. This work is licensed under the terms of the Creative Commons Attribution (CC BY) (http://creativecommons.org/licenses/by/4.0/). 


\begin{abstract}
Abstrak: Daya tahan diri yang lemah dan rapuh mengakibatkan gangguan kesejahteraan psikologi dan kelestarian pengajian dalam kalangan pelajar bidang perhubungan menolong di universiti awam di Terengganu. Kajian ini dilaksanakan bagi meneroka pengalaman pelajar bidang perhubungan menolong tentang daya tahan diri. Kajian ini merupakan kajian kualitatif. Data telah dikumpulkan melalui kaedah temu bual kumpulan fokus menggunakan protokol temu bual semi-struktur. Seramai 16 orang pelajar bidang perhubungan menolong telah terlibat dalam kajian ini. Pelajar bidang perhubungan menolong dalam konteks kajian ini merupakan pelajar yang sedang mengikuti pengajian Diploma Sains Kejururawatan, Diploma Radiografi, Sarjana Muda Kaunseling dan Sarjana Muda Perubatan dan Pembedahan di universiti awam Terengganu. Pemilihan informan menggunakan pendekatan persampelan bertujuan berstrata (stratified purposive sampling). Data dianalisis secara analisis tema. Hasil kajian mendapati informan mempunyai pengalaman cara untuk membentuk daya tahan diri serta bagaimana daya tahan diri dapat membantu mereka menyesuaikan diri dengan kehidupan di kampus. Kesimpulannya, dapatan kajian ini dapat menyumbang ke arah peningkatan ilmu pengetahuan berkaitan daya tahan diri seterusnya mempromosi dan memperkasakan daya tahan diri dalam kalangan pelajar bidang perhubungan menolong. Selaras dengan kepentingan daya tahan diri sebagai keperluan kepada penyesuaian kehidupan di kampus, maka pengkaji mencadangkan suatu intervensi berasaskan laman web (web-based intervention) yang bertujuan untuk mempromosi serta meningkatkan daya tahan diri pelajar bidang perhubungan menolong.
\end{abstract}

Kata kunci: Daya tahan diri, Terengganu, profesion menolong, kehidupan kampus

\title{
PENGENALAN
}

Menyambung pengajian ke peringkat universiti menjadi impian setiap individu yang bergelar pelajar. Apabila bercerita tentang cabaran kehidupan di kampus, timbul tanda tanya mengapa suatu cerita kehidupan kampus yang mempunyai permulaan yang sama namun mempunyai pengakhiran yang berbeza. Sebagai contoh dua orang pelajar perempuan dari kampung terpaksa berpisah dengan keluarga dan tinggal di kolej kediaman universiti yang jauh beribu-beribu batu dari keluarga serta dua orang pelajar lelaki dari sekolah yang sama memasuki bidang pengajian di universiti yang sama. Salah seorang daripada pelajar perempuan tersebut mampu menguruskan kehidupan mereka secara berdikari namun seorang lagi pula mengalami kesukaran untuk menguruskan kehidupan. Begitu juga dengan kisah pelajar lelaki, seorang mampu meneruskan kehidupan sehingga berjaya menamatkan pengajian namun seorang lagi pula mengalami kemurungan dan terkandas dalam pelajaran.

Paparan kisah ini merupakan secebis kisah kehidupan individu di universiti. Kisah ini menimbulkan persoalan mengapa dan bagaimana sesetengah individu lebih kuat apabila berhadapan cabaran yang melibatkan perubahan kehidupan di kampus 
berbanding sesetengah individu yang lain. Timbul juga persoalan adakah terdapat keadaan atau amalan kehidupan yang boleh meramalkan siapa yang lebih mampu berhadapan dengan perubahan kehidupan dan siapa yang kurang mampu. Wujud juga persoalan apakah ada perkara yang boleh kita lakukan untuk meningkatkan keupayaan individu berhadapan dengan cabaran perubahan kehidupan.

Menyambung pengajian ke peringkat pendidikan tinggi merupakan suatu cabaran perubahan dan memberikan impak kepada kehidupan individu (Turner, Holdsworth, \& Scott-Young, 2017). Antara perubahan ketara yang dirasai dan dihadapi oleh pelajar adalah peralihan sistem pembelajaran dari peringkat sekolah ke peringkat pendidikan tinggi (Turner, Scott-Young, \& Holdsworth, 2016). Peralihan sistem pembelajaran ini melibatkan transisi akademik dan peribadi yang mendedahkan pelajar universiti kepada persekitaran kehidupan yang mencabar dan memerlukan pelajar untuk membuat penyesuaian yang tinggi (Rahat \& Ilhan, 2016; Skovholt \& Ronnestad, 2003). Ketidakupayaan pelajar universiti untuk menangani transisi kehidupan ini akan mengganggu kesejahteraan hidup dan memberi kesan kepada pengajian mereka (Bayram \& Bilgel, 2008). Perubahan ini memerlukan pelajar membuat penyesuaian dan ia memerlukan daya tahan diri yang sangat tinggi (Wang, 2009). Kajian Erdogan, Ozdogan dan Erdogan (2015) yang menyokong kajian Wang (2009) menyatakan bahawa daya tahan diri dapat membantu pelajar universiti menguruskan transisi kehidupan di universiti (Erdogan et al., 2015; Wang, 2009).

Daya tahan diri dalam konteks pelajar perhubungan menolong adalah keupayaan untuk melantun kembali daripada tekanan yang berkaitan dengan akademik dan latihan profesion (Dyrbye et al., 2010). Kajian terdahulu menyatakan daya tahan diri dapat membantu pelajar bidang perhubungan menolong memperbaiki kualiti kehidupan, memberikan pandangan yang positif kepada persekitaran pembelajaran mereka serta membantu mencapai kejayaan dalam akademik (Tyre, Griffin, \& Simmons, 2016). Selain itu, daya tahan diri juga telah dikenal pasti sebagai salah satu faktor yang menyumbang kepada kejayaan pelajar bidang perhubungan menolong (Clark, Brooks, Lee, Daley, Crawford, \& Maxis, 2007).

Kajian yang dijalankan oleh Wang (2009) menyatakan bahawa daya tahan diri dapat membantu pelajar universiti mengatasi isu penyesuaian terhadap perubahan yang dihadapi oleh mereka (Wang, 2009). Keupayaan pelajar universiti menggunakan daya tahan diri membantu mereka menangani penyesuaian kehidupan memberi kesan kepada kesejahteraan psikologi, mental, spiritual, fizikal, budaya dan sosial (Stamm, 2010). Ia juga memberi kesan kepada kelestarian dalam pengajian dan pencapaian serta prestasi akademik (Barnett, Baker, Elman, \& Schoener, 2007; Pearcey \& Elliott, 2004). Oleh yang demikian, daya tahan diri menjadi keperluan 
kepada pelajar bidang perhubungan menolong untuk mereka kekal sejahtera dan lestari dalam pengajian (Lawson \& Myers, 2011). Melihat kepada kepelbagaian isu yang melanda pelajar universiti, maka adalah penting untuk memperkasakan daya tahan diri pelajar universiti sebagai keperluan penyesuaian kehidupan di kampus.

\section{TINJAUAN LITERATUR}

Daya tahan diri dikaitkan dengan keupayaan individu untuk menangani dan menyesuaikan diri apabila berhadapan dengan tragedi, trauma, kesusahan dan kesukaran (Connor \& Davidson, 2003). Konsep daya tahan diri secara umumnya adalah keupayaan individu untuk bangkit semula dan membina kekuatan selepas berhadapan dengan kesukaran dan cabaran (Mohd Tajudin \& Rohany, 2014). Perkataan daya tahan diri berasal dari istilah sains fizikal yang bermaksud "melantun atau bangkit semula" (to bounce back) atau pulih selepas kerugian (rebounding after loss) (Resnick \& Inguito, 2011). Mohd Tajudin dan Rohany (2014) menyatakan bahawa penggunaan istilah daya tahan diri menerangkan tentang keupayaan individu untuk melantun atau bangkit semula apabila berhadapan dengan kesukaran hidup. Istilah ini juga digunakan oleh Richardson (2002) untuk memberikan gambaran bahawa daya tahan diri membantu individu untuk meletakkan kembali dirinya pada paksi asal kehidupan selepas berhadapan dengan cabaran (Richardson, 2002).

Daya tahan diri dari perspektif psikologi adalah daya tahan diri yang menjadikan individu mampu menghadapi perubahan dalam hidup dan menganggap perubahan sebagai suatu peluang untuk kehidupan yang lebih baik (Bonanno, Romero, \& Klein, 2015). Kajian berkaitan daya tahan diri daripada perspektif psikologi adalah bertujuan untuk memahami bagaimana sesetengah individu mampu bertahan dengan tekanan yang dihadapi mereka, malah mereka semakin berkembang dan kuat setelah berhadapan dengan cabaran (Fletcher \& Sarkar, 2013). Daya tahan diri daripada perspektif psikologi menurut Richardson (2002) adalah peralihan paradigma individu diri dari melihat faktor risiko yang membawa kepada kerapuhan kepada mencari kekuatan diri. Pandangan ini disokong oleh Mohd Tajudin dan Rohany (2014) yang menyatakan bahawa individu yang mempunyai daya tahan diri tidak berisiko menjadi rapuh malah mempunyai faktor pelindung yang membentuk ketahanan diri.

Daya tahan diri dalam konteks pelajar universiti adalah keupayaan pelajar untuk menyesuaikan diri terhadap perubahan kehidupan yang serba baharu di universiti (Turner et al., 2016). Kehidupan di universiti merupakan suatu fasa kehidupan 
yang sukar kerana ia melibatkan perubahan yang besar (Rahat \& Ilhan, 2016). Perubahan utama yang dinyatakan dalam kajian sebelum ini adalah perubahan akademik dan peribadi (Skovholt \& Ronnestad, 2003; Turner et al., 2016). Turner et al. (2016) menyatakan perubahan akademik melibatkan transisi pendidikan iaitu dari sistem pengajian peringkat sekolah ke peringkat universiti (Turner et al., 2016). Kajian Skovholt dan Ronnested (2003) yang disokong oleh kajian Rahat dan Ilhan (2016) pula menyatakan perubahan peribadi melibatkan transisi kehidupan pelajar bersama keluarga kepada kehidupan sendiri dan berdikari (Rahat \& Ilhan, 2016; Skovholt \& Ronnestad, 2003).

Pelajar bidang perhubungan menolong berhadapan dengan cabaran untuk menyeimbangkan keperluan akademik, profesional, tanggungjawab peribadi dan latihan dalam profesion (Greenhill, Fielke, Richards, Walker, \& Walters, 2015; Thompson, Frick, \& Trice-Black, 2012). Pelajar bidang perhubungan menolong juga berhadapan risiko gangguan kesejahteraan seperti kemurungan, burn out sehingga kadang kala membawa kepada idea membunuh diri (Martin \& Marsh, 2006). Hal ini berlaku kerana kegagalan pelajar menyesuaikan diri dengan bidang pengajian baharu dan pelajar masih samar dengan kepelbagaian tanggungjawab serta peranan sebagai pelajar bidang perhubungan menolong (Thompson, McBride, Hosford, \& Halaas, 2016; Tyre et al., 2016). Penglibatan pelajar universiti dalam latihan profesion bidang perhubungan menolong pada peringkat awal memerlukan banyak penyesuaian kehidupan (Skovholt \& TrotterMathison, 2016). Antara penyesuaian yang diperlukan oleh pelajar adalah seperti penyesuaian akademik dan peribadi. Kedua-dua isu yang dinyatakan tersebut boleh memberi kesan secara langsung atau tidak langsung kepada diri pelajar dan latihan profesion mereka ketika di universiti (Barnett et al., 2007; Stamm, 2010).

Daya tahan diri yang lemah dan rapuh akan memberikan implikasi negatif terhadap perkembangan diri pelajar universiti. Ketiadaan dan kelemahan daya tahan diri mengakibatkan gangguan kepada kesejahteraan pelajar universiti (Derosier, Frank, Schwartz, \& Leary, 2013). Ketiadaan dan kelemahan daya tahan diri juga menjadikan individu cenderung untuk berfikir dan bertingkah laku dengan cara yang salah. Mereka juga berkemungkinan akan terlibat dengan masalah mental akibat daripada pelbagai perubahan psikososial dan tekanan akademik serta pembelajaran (Fauziah, Nazirah, \& Werdi Werdana, 2018). Di samping itu, mereka berkemungkinan akan mengalami tekanan yang akan membahayakan kesihatan fizikal dan mental mereka (Pfeiffer, 2001; Shamzaeffa \& Hong, 2016). Selain daripada masalah pembelajaran, gangguan emosi yang dihadapi juga kesan daripada masalah keluarga dan pembelajaran (Sherina, Lekhraj, \& Nadarajan, 2003). National Health and Morbidity Survey (NHMS) 2017 telah menjalankan kajian terhadap 30,496 orang responden dari 212 sekolah yang dipilih secara 
rawak di seluruh Malaysia (Institute for Public Health, 2018). Bilangan responden ini mewakili 5.5 juta orang remaja di Malaysia. Dapatan kajian menunjukkan 10\% responden mempunyai idea membunuh diri, $7.5 \%$ merancang untuk membunuh diri dan 6.9\% mempunyai cubaan untuk membunuh diri (Institute for Public Health, 2018). Kajian yang sama turut menunjukkan satu daripada lima belia mengalami kemurungan, manakala satu daripada 10 orang remaja berhadapan masalah tekanan perasaan (Sohana, 2019).

Menjalani kehidupan sebagai pelajar universiti menjadikan individu berhadapan dengan pelbagai cabaran. Selain daripada tekanan pembelajaran, pelajar universiti juga berhadapan dengan daya saing yang tinggi bagi memenuhi tuntutan dunia kerjaya profesional dalam bidang perhubungan menolong (Fauziah et al., 2018). Sebagai persediaan, pelajar universiti perlu menyiapkan dan menyesuaikan diri untuk berhadapan dengan perubahan kehidupan di kampus serta dengan masuk ke dunia kerjaya profesional yang lebih mencabar (Uehara, Takeuchi, Kubota, Oshima, \& Ishikawa, 2010). Antara kemahiran penting yang wajar diberikan adalah kemahiran membentuk daya tahan diri yang dapat membantu menghadapi tekanan persekitaran pembelajaran serta latihan dalam bidang perhubungan menolong dan seterusnya masuk ke dunia kerjaya profesional sebenar yang mencabar (Gheihman, Cooper, \& Simpkin, 2019).

Dapat dirumuskan bahawa pelajar universiti berhadapan dengan isu penyesuaian terhadap perubahan kehidupan di universiti. Mereka juga berhadapan dengan isu penyesuaian terhadap perubahan sebagai pelajar bidang perhubungan menolong yang merupakan latihan bidang profesional. Hal ini memberi kesan kepada kesejahteraan diri serta kelestarian pengajian mereka. Namun begitu, kajian terdahulu mendapati bahawa daya tahan diri menjadi sumber yang dapat membantu pelajar mengatasi isu penyesuaian dan mengekalkan kesejahteraan diri serta kelestarian pengajian mereka.

Sehubungan dengan itu, adalah penting untuk mengkaji dan meneroka sumber yang dikatakan dapat membantu pelajar universiti yang merupakan pelajar dalam bidang perhubungan menolong untuk mengekalkan kesejahteraan diri dan kelestarian dalam pengajian. Bertitik tolak daripada idea ini, maka kajian berkaitan daya tahan diri dalam kalangan pelajar universiti di dua buah universiti awam di Terengganu wajar dilaksanakan untuk membantu pelajar universiti serta pelajar bidang perhubungan menolong mengatasi isu penyesuaian dan seterusnya mengekalkan kesejahteraan diri serta kelestarian dalam pengajian. 


\section{OBJEKTIF}

Objektif kajian ini secara umumnya ialah untuk meneroka pengalaman daya tahan diri dalam kalangan pelajar bidang perhubungan menolong di dua buah universiti awam Terengganu. Secara khususnya, kajian ini meneroka definisi daya tahan diri, cara membentuk daya tahan diri dan cara daya tahan diri membantu sebagai pelajar universiti.

\section{METODOLOGI KAJIAN}

Kajian ini adalah kajian kualitatif. Data dikumpulkan melalui kaedah temu bual kumpulan fokus. Instrumen kajian adalah protokol temu bual semi-struktur. Protokol temu bual semi-struktur mengandungi empat bahagian soalan iaitu: (i) soalan pengenalan; (ii) soalan bagi memperkenalkan topik yang hendak dikaji; (iii) soalan kunci bagi menjawab persoalan kajian; dan (iv) soalan penutup (Ghazali \& Sufean, 2016; Krueger, 2002). Pembinaan protokol temu bual semi-struktur telah diadaptasi daripada Krueger (2002) serta Ghazali dan Sufean (2016).

Soalan-soalan protokol temu bual yang telah dibina dan disusun mengikut empat bahagian tersebut, telah diperiksa dan disemak oleh pakar bidang. Pakar bidang merupakan profesor di universiti awam yang mempunyai kelayakan Doktor Falsafah dan mempunyai pengalaman lebih 20 tahun sebagai penyelidik dalam bidang kaunseling. Pengkaji seterusnya telah menjalankan temu bual rintis untuk menguji, mendapatkan maklum balas serta menyemak soalan dalam protokol temu bual semi-struktur sebelum digunakan dalam kajian sebenar (Bowen, Rose, \& Pilkington, 2017). Semua informan yang terlibat dalam kajian rintis ini tidak dipilih dalam kajian sebenar.

Pemilihan sampel kajian dalam kajian ini menggunakan pendekatan persampelan bertujuan strata (stratified purposive sampling) sebagaimana yang dicadangkan oleh Teddlie dan Tashakkori (2009). Proses persampelan dimulakan dengan mengenal pasti sub-kumpulan sampel berdasarkan kriteria yang telah ditetapkan dan kemudiannya memilih sampel dari setiap sub-kumpulan secara bertujuan (Teddlie \& Tashakkori, 2009). Kriteria pemilihan sampel dalam konteks kajian ini dimulakan dengan menetapkan kriteria iaitu pelajar bidang perhubungan menolong di dua buah universiti awam di Terengganu. Sub-kumpulan sampel yang dipilih adalah terdiri daripada pelajar Sarjana Muda Perubatan dan Pembedahan, pelajar Sarjana Muda Kaunseling, pelajar Diploma Sains Kejururawatan dan pelajar Diploma Radiografi. Seterusnya adalah pemilihan sampel dari setiap subkumpulan tersebut bagi tujuan temu bual kumpulan fokus. Sampel ini dikenali 
sebagai informan. Seramai 16 orang informan telah terlibat dalam kajian ini. Pecahan bilangan informan adalah lima orang informan adalah pelajar Sarjana Muda Perubatan dan Pembedahan, lima orang informan adalah pelajar Sarjana Muda Kaunseling dan enam orang informan adalah pelajar Diploma Sains Kejururawatan.

Temu bual kumpulan fokus dalam kajian sebenar telah dilaksanakan secara bersemuka dengan informan. Semua maklumat yang diperoleh daripada informan direkodkan dalam buku nota lapangan dan juga direkodkan dengan menggunakan pita rakaman audio. Penggunaan pita rakaman audio digunakan kerana pelaksanaan rakaman menggunakan video agak sukar untuk dilaksanakan di seting kajian. Proses penganalisisan data temu bual dimulakan dengan pengkaji mentranskripsikan pita rakaman audio tersebut ke dalam bentuk verbatim (petikan temu bual sebenar) yang terdiri daripada perkataan demi perkataan dan ayat demi ayat. Setelah penulisan verbatim siap dilaksanakan, pengkaji menghantar verbatim data temu bual kumpulan fokus kepada informan untuk tujuan semakan kandungan.

Menurut Ghazali dan Sufean (2016), semakan kandungan dilaksanakan bagi memastikan tahap kesahan data yang diperoleh. Informan seterusnya membuat semakan silang pita rakaman audio dan verbatim yang ditulis. Mereka dibenarkan untuk membuat pembetulan terhadap kesilapan fakta yang berlaku dalam verbatim. Setelah itu, informan menyatakan perakuan persetujuan terhadap kandungan verbatim tersebut. Proses ini adalah penting dilaksanakan sebelum memulakan analisis data. Ia bertujuan untuk memastikan data kualitatif yang diperoleh daripada informan adalah tepat (Ghazali \& Sufean, 2016).

Setelah pengkaji mendapat semula verbatim yang telah disemak dan dipersetujui oleh informan, pengkaji kemudiannya menyusun dan mengasingkan data mengikut kepentingan data. Dalam kajian ini, pengkaji menyusun dan mengasingkan data mengikut sistem kod. Tujuan sistem kod ini dibuat adalah bagi memudahkan proses analisis tema. Pembinaan sistem kod dalam kajian ini diadaptasi daripada Ghazali dan Sufean (2016). Jadual 1 menunjukkan keterangan kod informan.

Setelah proses pembinaan kod selesai, maka pengkaji seterusnya membuat pembinaan kategori ataupun subtema. Bagi memastikan semua bahagian transkripsi habis dikelompokkan mengikut kategori atau subtema, maka pengkaji telah membaca transkripsi secara berulang kali. Proses terakhir dalam analisis data kualitatif ini adalah proses penetapan tema. Setelah penetapan tema dibuat, pengkaji mendapatkan pengesahan pakar terhadap tema yang telah dibina. Pakar yang mengesahkan tema adalah Profesor dalam bidang kaunseling yang mempunyai 
pengalaman dalam bidang penyelidikan kualitatif. Pakar juga merupakan penyelia Doktor Falsafah penyelidik. Tema kemudiannya disusun secara sistematik bagi memudahkan analisis dan penulisan laporan.

Jadual 1. Keterangan kod informan

\begin{tabular}{ll}
\hline Kod & Keterangan \\
\hline INF1 & Nombor bilangan informan \\
FGD1 & Kumpulan fokus yang pertama \\
NURSING & Nama kumpulan informan \\
IN1 & Nama informan yang pertama \\
TB1 & Temu bual sesi pertama \\
22.2 .2017 & Tarikh temu bual diadakan \\
(UNISZA) & Tempat temu bual diadakan \\
\hline
\end{tabular}

\section{KEPUTUSAN KAJIAN}

Bahagian ini melaporkan hasil daripada analisis tema berdasarkan temu bual kumpulan fokus yang berpandukan kepada protokol temu bual semi-struktur. Pelaporan bahagian ini melibatkan dapatan kajian pengalaman informan berkaitan definisi daya tahan diri, cara membentuk daya tahan diri dan bagaimana daya tahan diri membantu sebagai pelajar universiti. Berikut merupakan perincian bagi definisi daya tahan diri, cara membentuk daya tahan diri dan cara daya tahan diri membantu sebagai pelajar universiti.

\section{Definisi Daya Tahan Diri}

Hasil kajian menunjukkan pelajar bidang perhubungan menolong mendefinisikan daya tahan diri sebagai penyelesaian masalah, diri-sendiri, emosi, positif, spiritual dan kognitif. Mereka menyatakan tema penyelesaian masalah adalah berkaitan cara mengurus masalah, kemahiran daya tindak, kemampuan menghadapi masalah, kemampuan mengurus masalah dan penerimaan masalah. Mereka juga menyatakan tema diri-sendiri adalah integriti, kemampuan diri, menerima apa yang dihadapi dan motivasi diri. Informan juga menyatakan tema emosi adalah berkaitan kemampuan mengawal emosi, kemampuan mengurus emosi dan kesabaran. Hasil kajian yang menunjukkan pelajar bidang perhubungan menolong mendefinisikan daya tahan diri sebagai penyelesaian masalah, diri-sendiri, emosi, positif, spiritual dan kognitif sebagaimana yang dinyatakan oleh informan dalam Jadual 2. 
Jadual 2. Pernyataan informan tentang definisi daya tahan diri

\begin{tabular}{ll}
\hline Tema & Petikan temu bual \\
\hline Emosi / Penyelesaian & "Daya tahan diri ni macam kemampuan kita kan.. Kemampuan \\
masalah & saya ni dalam menghadapi masalah tu, kita nak adapt dengan \\
& situasi semua. dengan emosi kita lagi kan. Nak jaga perasaan orang \\
& lagi, nak jaga perasaan sendiri lagi"
\end{tabular}

Penyelesaian masalah

(FGD1/Nursing/Inf2/21.2.17/UNISZA)

Penyelesaian masalah

Diri-sendiri

Kognitif

Positif

Spiritual
"Bagaimana nak handle masalah tu, macam kalau ada masalah jangan pikirlah kalau saya boleh settle saya settle, kalau tak boleh esok, kalau tu lusa pulak. Jadi macam kalau tak boleh settle ari tu saya tak akan fikir cam saya tak fikir masalah lain ke ape kan. Saya tak kan bebankan fikir benda tu sampai serabut kepala. Baik saya gi main ke ape ke....macam tu lah"

(FGD1/Nursing/Inf5/21.2.17/UNISZA)

"Kalau daya tahan diri tu bila kita ada masalah eh? Macam mana kita nak adapt dengan masalah tu."

(FGD2/Kaunseling/Inf3/22.2.17/UMT)

"Bagi saya pula cara untuk kita menstabilkan keadaan diri kita dengan masalah lah"

(FGD2/Kaunseling/Inf5/22.2.17/UMT)

"Saya kalau ada masalah cuba untuk dop fikir sangat. Macam saya sibukkan diri dulu. Macam buat benda yang kita suka sebab kalau selalu fikir jadi tak boleh nak fikir terus. Jadi, macam buat bendabenda lain dulu, tenang-tenang dulu baru boleh cari.....berfikir dengan tenang dulu, selesai dan menghadapi benda tu"

(FGD2/Kaunseling/Inf4/22.2.17/UMT)

"Kita hadapi satu masalah tu macam mana kita nak kekalkan kita punya positif tu. Walaupun kita hadap benda tu. Ha....macam mana kita nak be ourself yang positif lah...walaupun benda tu kena hadapi halangan"

(FGD4/Medic/Inf2/23.3.17/UNISZA)

"Negative thinking memang ada. Macam Ya Allah nak buat ni lah, buat ni lah. Macam kita baca kes orang bunuh diri semua tu kan. semua benda tu pop out lah tapi kita macam kena maintain lah kita punya iman semua memang kena kawal semua benda tu".

(FGD4/Medic/Inf4/23.3.17/UNISZA) 


\title{
Cara Membentuk Daya Tahan Diri
}

Hasil kajian menunjukkan pelajar bidang perhubungan menolong menyatakan cara membentuk daya tahan diri adalah melalui individu yang signifikan, diri-sendiri dan susunan kelahiran. Hasil kajian menunjukkan informan menyatakan cara membentuk daya tahan diri mereka juga adalah melalui persekitaran membesar dan pengalaman hidup yang berulang. Cara membentuk daya tahan diri adalah sebagaimana yang dinyatakan oleh informan dalam Jadual 3.

Jadual 3. Pernyataan informan tentang cara membentuk daya tahan diri

\begin{tabular}{ll}
\hline Tema & Petikan temu bual \\
\hline $\begin{array}{l}\text { Susunan } \\
\text { kelahiran }\end{array}$ & "Saya anak sulung. Sorang jer perempuan. Jadi macam manja sikit. Gitulah. \\
& Kalau ada apa-apa masalah pun sejak daripada kecil sampai sekarang ni \\
& memang mak jer. Pastu kalau macam ada apa-apa pun mak jer yang tahu"
\end{tabular}

(FGD1/Nursing/Inf2/21.2.17/UNISZA)

Diri sendiri

\begin{abstract}
"Saya nak tambah. Apa-apa yang kita buat kan mesti depend pada diri kita sendiri macam mana kita nak adapt dengan situasi tu. Bagi saya diri sendiri lah. Contoh kita ada masalah dengan assignment group ke apa, macam mana diri kita sendiri ni nak adapt dengan orang-orang yang macam tu. Fikiran positif yang Nik cakap tadi pun memang perlu lah. sabar. Apa-apa pun yang berlaku semua pada diri kita sendiri lah"
\end{abstract}

(FGD2/Kaunseling/Inf3/22.2.17/UMT)

Diri sendiri/

Pengalaman hidup yang berulang

Diri sendiri/ Individu yang signifikan

Persekitaran membesar
"Macam saya pulak, saya setuju dengan Aina. Ia datang daripada diri sendiri juga. Macam kita perlu belajar daripada pengalaman lah. maksudnya di sini macam kita kena sahut cabaran juga lah. kita cuba ini, cuba ini. Pengalaman mengajar kita jadi lebih berupaya untuk semua keadaan lah"

(FGD2/Kaunseling/Inf5/22.2.17/UMT)

"Saya macam sama jugak lah. Macam ibu bapa, kawan-kawan dan orang sekeliling tu penting lah. Sebab kadang-kadang tu kalau kita rasa tak mampu mungkin orang sekeliling, kawan-kawan, ibu bapa boleh tolong kita. Pastu saya ni macam jenis tak suka share masalah saya dengan orang lain. Sebab macam tak tahu lah. Kalau ada apa-apa saya sorang je. Pendam je. Tapi saya perlukan jugak kawan-kawan kalau ada masalah ke apa saya ajak dia orang keluar, buat benda yang boleh hilangkan stress, masalah ke"

(FGD2/Kaunseling/Inf4/22.2.17/UMT)

"Kalau bagi saya, mungkin persekitaran saya membesar macam tu. Kalau macam family saya, kalau nak marah tu dia macam geram ke, dia marah jer. Ada tu macam saya senyap. Ada tu kalau nak marah ye akan marah. Kalau saya, nak cerita ape-ape kat orang macam masalah lah, saya akan fikir dua tiga kali. Sama ada saya boleh percaya kat dia atau tidak. Sebab tu saya akan pendam"

(FGD1/Nursing/Inf2/21.2.17/UNISZA) 


\title{
Cara Daya Tahan Diri Membantu Sebagai Pelajar Universiti
}

Hasil kajian menunjukkan pelajar bidang perhubungan menolong menyatakan cara daya tahan diri membantu informan sebagai pelajar universiti dari sudut pembinaan personaliti, mengawal emosi dan hubungan interpersonal. Pernyataan tentang cara daya tahan diri membantu sebagai pelajar universiti adalah sebagaimana yang dinyatakan oleh informan dalam Jadual 4.

Jadual 4. Pernyataan informan tentang cara daya tahan diri membantu sebagai pelajar universiti

\begin{tabular}{ll}
\hline Tema & Petikan temu bual \\
\hline Mengawal emosi & "Kalau macam saya, masa kita praktikal. Kena marah ke ape ke. Mungkin \\
& masa kita kena marah tu kita senyap jer. Senyum-senyum. Pastu bila kita \\
& tak tahan tu, kita cerita dekat kawan. Kita tak pendam. Macam tu lah"
\end{tabular}

(FGD1/Nursing/Inf2/21.2.17/UNISZA)

Mengawal emosi

/ Hubungan

interpersonal

\begin{abstract}
"Tadi contoh saya dah cerita yang assignment kan. Bila kita berhadapan dengan orang yang tak selalu kita jumpa. Ada perangai-perangai dia yang macam tu. Jadi kat situ macam mana cara kita berkomunikasi dengan orang tu kan. Kalau dia jenis yang tinggi suara tak kan lah kita pun nak tinggi suara kan. Daripada situ kita belajar macam mana kita nak kontrol suara kita semua tu kan. Pastu, maknanya nanti tu macam pengalaman pada diri kita lah bila jumpa orang yang macam tu. Lepas ni kalau kita jumpa orang yang sama macam tu macam mana kita act kan. Pastu belajar daripada yang tu lah. So tak payah nak fikir dia banyak bagi masalah, banyak buat masalah kan. Tak kan kita nak fikir benda-benda macam tu. pada diri kita lah, kita ubah sikit-sikit. Pasni mungkin kita akan lalui benda yang sama macam tu"
\end{abstract}

(FGD2/Kaunseling/Inf3/22.2.17/UMT)

Hubungan interpersonal

\begin{abstract}
"Saya rasa sebagai student ni kena positif dalam semua perkara. Sebab contohnya tadi, hubungan dengan rakan-rakan saya rasa kalau kita nak suruh orang tu ikut cakap kita memang tak boleh sebab orang tu....... setiap orang lain cara, lain pandangan dia. Kita perlulah...kadang-kadang kita perlu follow je orang.....ape ni nak kata”
\end{abstract}

(FGD2/Kaunseling/Inf2/22.2.17/UMT)

\section{PERBINCANGAN KAJIAN}

Pengukuran pengalaman informan tentang daya tahan diri dalam kalangan pelajar bidang perhubungan menolong di universiti awam di Terengganu meliputi definisi daya tahan diri, cara membentuk daya tahan diri dan cara daya tahan diri membantu sebagai pelajar universiti. Adalah diharapkan dapatan kajian 
daripada semua tema ini dapat membantu memperbaiki atau menambahbaik tahap daya tahan diri yang harus diterapkan di kalangan pelajar universiti. Ini kerana daya tahan diri dilihat menjadi suatu keperluan kepada penyesuaian kehidupan di kampus. Informan mendefinisikan daya tahan diri sebagai keupayaan penyelesaian masalah, diri-sendiri, emosi, positif, spiritual dan kognitif. Kefahaman yang dinyatakan oleh informan ini adalah berdasarkan kepada proses dinamik hasil pembelajaran mereka terhadap persekitaran serta pengalaman kehidupan (Himmel, 2015; Richardson, 2002).

Hasil analisis tema bagi cara membentuk daya tahan diri yang dinyatakan oleh informan dalam temu bual menunjukkan pembentukan daya tahan diri adalah melalui individu yang signifikan, diri-sendiri dan susunan kelahiran. Hasil daripada analisis temu bual kumpulan fokus, informan menyatakan cara membentuk daya tahan diri juga adalah melalui persekitaran membesar dan pengalaman hidup yang berulang. Dapatan kajian ini menyokong kajian yang dijalankan oleh Richardson (2002) yang menyatakan bahawa daya tahan diri diperoleh daripada persekitaran dan diwarisi daripada genetik keluarga. Dapatan kajian ini juga menyokong dapatan kajian Grafton et al., (2010) yang menyatakan bahawa daya tahan diri boleh dipelajari dan dibentuk. Pembelajaran dan pembentukan daya tahan diri individu berdasarkan kepada faktor psikologi, biologi dan sokongan sosial (Grafton et al., 2010).

Dapatan kajian ini adalah selaras dengan pandangan Norris (2010) yang menyatakan bahawa pada abad ke-20 ini, daya tahan merupakan tingkah laku dan sikap yang boleh dipelajari. Norris (2010) menyatakan bahawa daya tahan diri berupaya ditingkatkan melalui latihan. Dyrbye dan Shanafelt (2012) juga berpandangan bahawa latihan berterusan berkaitan daya tahan diri membantu pelajar menyesuaikan diri merentasi persekitaran dan cabaran. Ia juga boleh melindungi pelajar daripada pelbagai tekanan yang timbul semasa latihan dan sepanjang kerjaya dalam bidang perubatan (Dyrbye \& Shanafelt, 2012).

Gheihman et al. (2019) juga telah menjalankan kajian berkaitan isu daya tahan diri dalam kalangan pelajar perubatan tahun pertama di Fakulti Perubatan di Massachusetts General Hospital. Keseluruhan dapatan kajian menunjukkan informan menyatakan bahawa mereka kurang pengetahuan dan tiada latihan berkaitan daya tahan diri. Hasil kajian beliau menunjukkan $71 \%$ daripada informan menjelaskan tiada pendedahan atau mendapat pendedahan yang sangat sedikit kepada kemahiran daya tahan diri manakala 94\% lagi informan merasakan tidak menerima latihan mencukupi tentang daya tahan diri (Gheihman et al., 2019). Hasil dapatan kajiannya, Gheihman et al. (2019) mencadangkan pelaksanaan kursus atau modul easy-to-teach resilience tools kepada semua 
pelajar perubatan di Fakulti Perubatan di Massachusetts General Hospital. Kajian Gheihman et al. (2019) ini menyokong kajian Tyre et al. (2016) yang menyatakan bahawa daya tahan diri dapat membantu pelajar bidang perhubungan menolong memperbaiki kehidupan mereka, membina pandangan yang positif terhadap pembelajaran mereka serta membantu mencapai kejayaan (Tyre et al., 2016)

Informan kajian ini mengiktiraf konstruk daya tahan diri sebagai suatu tret yang dapat membantu mereka dalam kehidupan seharian di kampus. Di samping itu, daya tahan diri juga telah dibuktikan dapat membantu pelajar bidang perhubungan menolong untuk menangani fasa transisi kehidupan di universiti dan ia menyumbang kepada kesejahteraan dan kesihatan mental mereka (Derosier et al., 2013; Dunn, Iglewicz, \& Moutier, 2008). Selain itu, daya tahan diri juga membantu menyediakan diri pelajar universiti untuk berhadapan dengan realiti sebenar profesion dalam bidang perhubungan menolong (Jimenez, Navia-Osorio, \& Diaz, 2010).

Berdasarkan kepada keseluruhan perbincangan dapatan kajian ini, pengkaji berpandangan bahawa pembinaan dan pembentukan daya tahan diri dalam kalangan pelajar universiti boleh dilaksanakan dengan memberikan ilmu pengetahuan dan pendedahan serta memberikan latihan berstruktur yang mencukupi tentang daya tahan diri. Sehubungan dengan itu, bagi mencapai objektif pembinaan dan pembentukan daya tahan diri dalam kalangan pelajar universiti, pengkaji terdahulu telah mencadangkan daya tahan diri dijadikan ko-kurikulum di universiti dengan pemantauan pelaksanaan dilakukan secara berterusan mengikut tahun pengajian pelajar.

\section{CADANGAN}

Secara kesimpulan, dapatan kajian ini menunjukkan pengalaman, pengetahuan dan kefahaman informan tentang daya tahan diri serta ciri individu yang mempunyai daya tahan diri adalah baik dan memuaskan. Hasil kajian turut menunjukkan informan mengetahui cara pembentukan daya tahan diri yang baik melalui kawalan emosi positif serta berkemampuan untuk membuat penyesuaian diri. Keadaan ini menggambarkan bahawa pelajar universiti yang juga merupakan pelajar bidang perhubungan menolong di universiti awam di Terengganu menunjukkan kemampuan menangani cabaran. Mereka juga mampu keluar daripada masalah walaupun berhadapan dengan situasi kehidupan yang sukar. 
Walaupun secara keseluruhannya kajian ini mendapati tahap pengalaman, pengetahuan dan kefahaman informan berkaitan daya tahan diri adalah baik dan memuaskan, namun penekanan dan pemerkasaan aspek daya tahan masih perlu dititikberatkan. Fokus pemerkasaan daya tahan diri dalam konteks kajian ini adalah dari aspek daya tahan diri kognitif, emosi, tingkah laku dan spiritual (Neenan, 2009; Yatimah \& Mohd Tajudin, 2008). Sehubungan dengan itu, adalah relevan untuk mengembangkan intervensi daya tahan diri khusus kepada pelajar universiti bagi memupuk persekitaran dan komuniti yang berdaya tahan diri.

Mitchell, Vella-Brodrick dan Klein (2010) memperkenalkan suatu intervensi yang menggabungkan psikologi positif dan intervensi atas talian khusus untuk mempromosikan kesejahteraan. Beliau memperkenalkan terma intervensi psikologi positif atas talian (online positive psychology interventions [OPPI]). Intervensi psikologi positif atas talian dalam konteks penulisan ini bermaksud penerapan psikologi positif menggunakan pendekatan teknologi untuk meningkatkan kualiti pengalaman personal individu (Mitchell et al., 2010). Ia bertujuan untuk meningkatkan kesejahteraan diri, menjana kekuatan psikologi dan membina daya tahan diri. Intervensi ini melibatkan individu, organisasi dan ahli komuniti (Baños, Etchemendy, Mira, Riva, Gaggioli, \& Botella, 2017).

Pengkaji berpendapat intervensi psikologi positif atas talian ini sesuai dilaksanakan di Malaysia dengan mengambil kira data penggunaan internet yang dikeluarkan oleh Suruhanjaya Komunikasi dan Multimedia Malaysia (2018). Laporan Suruhanjaya Komunikasi dan Multimedia Malaysia melalui info grafik yang bertajuk Internet Users Survey 2018 menyatakan sejumlah $87.4 \%$ (28.7 juta orang) daripada penduduk Malaysia merupakan pengguna internet. Dari sudut umur pula, individu dalam kumpulan usia 20-an merupakan pengguna internet paling ramai dalam kalangan penduduk Malaysia. Di samping itu, gelagat perkongsian kandungan online yang paling tinggi adalah berkaitan pendidikan dengan jumlah $71.3 \%$ pengguna (Suruhanjaya Komunikasi dan Multimedia Malaysia, 2018). Selain itu, intervensi psikologi positif atas talian ini juga dilihat mampu memenuhi keperluan pelajar universiti yang digelar sebagai Digital Native oleh Herrero et al. (2019). Digital Native adalah istilah yang dicipta oleh Mark Prensky pada tahun 2001 yang digunakan untuk menggambarkan generasi yang membesar dalam era teknologi. Mereka ini selesa dengan teknologi dan komputer sejak kecil dan menganggap teknologi adalah sebahagian daripada keperluan kehidupan mereka (Herrero et al., 2019). 
Mengadaptasikan idea intervensi psikologi positif atas talian serta mengambil kira faktor kecekapan penggunaan internet dalam kalangan pelajar universiti di Malaysia, pengkaji mencadangkan suatu strategi intervensi psikologi positif atas talian melalui laman sesawang yang dinamakan sebagai e-Intervensi Daya Tahan Diri (eIDTD). Objektif utama eIDTD ini adalah untuk mempromosikan serta memperkasakan daya tahan diri pelajar universiti terutamanya pelajar bidang perhubungan menolong. Fokus pemerkasaan daya tahan diri dalam konteks eIDTD ini adalah dari sudut daya tahan diri kognitif, emosi, tingkah laku dan spiritual (Nor Ezdianie, 2020). Pengkaji mencadangkan komponen daya tahan diri yang boleh diaplikasikan dalam eIDTD ini diadaptasi daripada gabungan antara Teori Tingkah Laku Kognitif dan teori Psiko-spiritual al-Ghazali (Neenan, 2009; Yatimah \& Mohd Tajudin, 2008).

Cadangan reka bentuk eIDTD ini adalah dengan mengambil kira norma, budaya dan agama masyarakat Malaysia. eIDTD ini merupakan suatu intervensi aplikasi kendiri yang diadaptasi dari Palma-Gómez et al. (2020). Sehubungan dengan itu, eIDTD ini dicadangkan mengandungi dua elemen utama iaitu Kapsul Psiko Pendidikan Daya Tahan Diri dan Instrumen Penilaian Kendiri Daya Tahan Diri. Elemen Kapsul Psiko Pendidikan Daya Tahan Diri mengandungi lima modul iaitu Pengenalan kepada Daya Tahan Diri, Daya Tahan Diri Kognitif, Daya Tahan Diri Emosi, Daya Tahan Diri Tingkah Laku dan Daya Tahan Diri Spiritual. Elemen Instrumen Penilaian Daya Tahan Diri mengandungi Latihan dan Ujian Kendiri Daya Tahan Diri. Cadangan bagi melaksanakan eIDTD sebagai strategi intervensi kerana ia mampu meningkatkan kebolehcapaian dan kelestarian pengguna kepada promosi daya tahan diri. Ia dilihat berupaya memberikan banyak kelebihan kepada pengguna. Pengguna dapat membuat penilaian kendiri serta memantau daya tahan diri mereka (Palma-Gómez et al., 2020).

Secara keseluruhannya, kajian ini diharapkan dapat memberikan implikasi dan maklumat yang penting kepada pengamal kaunseling serta pengkaji akan datang. Adalah diharapkan agar pengamal kaunseling mempertimbangkan cadangan pelaksanan intervensi psikologi positif atas talian sebagai salah satu sumber sokongan yang dapat membantu meningkatkan dan memperkasakan daya tahan diri pelajar universiti. Pelaksanaan intervensi psikologi positif atas talian juga dilihat mempunyai potensi untuk dikembangkan (Baños et al., 2017; Mitchell et al., 2010). Adalah diharapkan agar pengkaji akan datang, dapat menjalankan kajian untuk membina modul dan laman sesawang eIDTD. Pengkaji akan datang juga dicadangkan untuk menilai keberkesanan eIDTD ini. Kesimpulannya, idea intervensi psikologi positif atas talian melalui eIDTD ini dicadangkan untuk 
memperkasakan daya tahan diri pelajar universiti dalam usaha mengekalkan kesejahteraan psikologi, mental, fizikal, budaya, sosial dan kelestarian pengajian mereka (Lawson \& Myers, 2011; Stamm, 2010).

\section{KESIMPULAN}

Hasil kajian ini memberi implikasi positif kepada beberapa pihak termasuklah pihak pengurusan tertinggi universiti, pusat kaunseling universiti, kaunselor serta pelajar bidang perhubungan menolong. Hasil kajian ini dapat membantu pihak pengurusan universiti merangka suatu kurikulum untuk mempertingkatkan tahap daya tahan diri dalam kalangan pelajar universiti. Di samping itu, dapatan kajian ini dapat membantu pihak pengurusan universiti memberikan latihan yang khusus dan berterusan kepada kaunselor untuk mereka menguasai pengetahuan, kemahiran dan meningkatkan kompetensi kaunselor berkaitan aspek daya tahan diri bagi memudahkan mereka melaksanakan program-program intervensi kaunseling berkaitan daya tahan diri untuk para pelajar universiti yang memerlukan. Dapatan kajian ini juga dapat membantu pihak kaunselor dan pusat kaunseling universiti merangka suatu modul intervensi daya tahan diri khusus untuk meningkatkan daya tahan diri pelajar bidang perhubungan menolong. Hasil kajian ini juga dapat membantu pelajar bidang perhubungan menolong meningkatkan pengetahuan dan kemahiran mereka dalam aspek daya tahan diri. Mereka juga disarankan untuk mendapatkan latihan bagi mempelajari cara membentuk daya tahan diri bagi membantu mereka untuk menjalani kehidupan kampus dengan lebih baik lagi. Secara keseluruhannya, dapatan kajian ini dapat membantu usaha meningkatkan dan memperkasakan daya tahan diri pelajar bidang perhubungan menolong serta menjadi pemangkin bagi membantu mereka mengatasi isu penyesuaian dan seterusnya mengekalkan kesejahteraan diri serta kelestarian dalam pengajian.

\section{RUJUKAN}

Baños, R. M., Etchemendy, E., Mira, A., Riva, G., Gaggioli, A., \& Botella, C. (2017). Online positive interventions to promote well-being and resilience in the adolescent population: A narrative review. Frontiers in Psychiatry, 8(January), 1-9. https://doi.org/10.3389/fpsyt.2017.00010

Barnett, J. E., Baker, E., Elman, N. S., \& Schoener, G. R. (2007). In pursuit of wellness: The self-care imperative. Professional Psychology: Research and Practice, 38, 603-612. 
Bayram, N., \& Bilgel, N. (2008). The prevalence and socio-demographic correlations of depression, anxiety and stress among a group of university students. Social Psychiatry and Psychiatric Epidemiology, 43, 667-672. https://doi.org/10.1007/ s00127-008-0345-x

Bonanno, G. A., Romero, S. A., \& Klein, S. I. (2015). The temporal elements of psychological resilience: An integrative framework for the study of individuals, families, and communities. Psychological Inquiry, 26(2), 139-169. https://doi.org/10.1080/1047840X.2015.992677

Bowen, P., Rose, R., \& Pilkington, A. (2017). Mixed methods-theory and practice: Sequential, explanatory approach. International Journal of Quantitative and Qualitative Research Methods, 5(2), 10-27.

Clark, M. A. N. N., Brooks, M., Lee, S. M. I. N., Daley, L. P., Crawford, Y., \& Maxis, S. (2007). Factors influencing the educational success of minority pre-service educators. Journal of College Student Retention: Research, Theory \& Practice, $8(1), 121-135$.

Connor, K. M., \& Davidson, J. R. T. (2003). Development of a new resilience scale: The Connor-Davidson Resilience Scale (CD-RISC). Depression and Anxiety, 18(2), 76-82. https://doi.org/10.1002/da.10113

Derosier, M. E., Frank, E., Schwartz, V., \& Leary, K. A. (2013). The potential role of resilience education for preventing mental health problems for college students. Psychiatric Annals, 43(12), 538-544. https://doi.org/10.3928/00485713 -20131206-05

Dunn, L. B., Iglewicz, A., \& Moutier, C. (2008). Promoting resilience and preventing burnout. Academic Psychiatry: The Journal of the American Association of Directors of Psychiatric Residency Training and the Association for Academic Psychiatry, 32(February), 44-53. https://doi.org/10.1176/appi.ap.32.1.44

Dyrbye, L. N., Power, D. V., Stanford Massie, F., Eacker, A., Harper, W., Thomas, M. R., Szydlo, D. W., Sloan, J. A., \& Shanafelt, T. D. (2010). Factors associated with resilience to and recovery from burnout: A prospective, multi-institutional study of US medical students. Medical Education, 44(10), 1016-1026. https://doi.org/10.1111/j.1365-2923.2010.03754.x

Dyrbye, L., \& Shanafelt, T. (2012). Nurturing resiliency in medical trainees. Medical Education, 46, 343-344. https://doi.org/10.1111/j.1365-2923.2011.04206.x

Erdogan, E., Ozdogan, O., \& Erdogan, M. (2015). University students' resilience level: The effect of gender and faculty. Procedia - Social and Behavioral Sciences, 186, 1262-1267. https://doi.org/10.1016/j.sbspro.2015.04.047

Fauziah, I., Nazirah, H., \& Werdi Werdana, A. S. (2018). Mengukur tahap ketahanan diri mahasiswa B40 dalam kalangan pelajar universiti (Measuring resiliency in B40 among university students). Jurnal Personalia Pelajar, 21(1), 19-27.

Fletcher, D., \& Sarkar, M. (2013). Psychological resilience. European Psychologist, 18(1), 12-23. https://doi.org/10.1027/1016-9040/a000124

Ghazali, D., \& Sufean, H. (2016). Metodologi penyelidikan dalam pendidikan: Amalan dan analisis kajian. Kuala Lumpur: Penerbit Universiti Malaya. https://doi .org/10.1080/00141840701219510 
Gheihman, G., Cooper, C., \& Simpkin, A. (2019). Everyday resilience: Practical tools to promote resilience among medical students. Journal of General Internal Medicine, 34(4), 498-501. https://doi.org/10.1007/s11606-018-4728-8

Grafton, E., Gillespie, B., \& Henderson, S. (2010). Resilience: The power within. Oncology Nursing Forum, 37(6), 698-705. https://doi.org/10.1188/10.ONF.698-705

Greenhill, J., Fielke, K. R., Richards, J. N., Walker, L. J., \& Walters, L. K. (2015). Towards an understanding of medical student resilience in longitudinal integrated clerkships. BMC Medical Education, 15(137), 1-9. https://doi.org/10.1186/ s12909-015-0404-4

Herrero, R., Mira, A., Cormo, G., Etchemendy, E., Baños, R., García-Palacios, A., Ebert, D. D., Franke, M., Berger, T., Schaub, M. P., Görlich, D., Jacobi, C., \& Botella, C. (2019). An Internet based intervention for improving resilience and coping strategies in university students: Study protocol for a randomized controlled trial. Internet Interventions, 16(March), 43-51. https://doi.org/10.1016/j.invent .2018 .03 .005

Himmel, J. P. (2015). The understanding and promotion of resilience in college students (doctoral dissertation), Antioch University, New England. Retrieved from https://aura.antioch.edu/cgi/viewcontent.cgi?article=1261\&context=etds

Institute for Public Health. (2018). National Health and Morbidity Survey (NHMS) 2017: Key findings from the Adolescent Health and Nutrition Surveys - Infographic Booklet April 2018. In National Health and Morbidity Survey (NHMS) 2017 Overview report (Issue April). Retrieved from http://www.iku.gov.my

Jimenez, C., Navia-Osorio, P. M., \& Diaz, C. V. (2010). Stress and health in novice and experienced nursing students. Journal of Advanced Nursing, 66(2), 442-455. https://doi.org/10.1111/j.1365-2648.2009.05183.x

Krueger, R. (2002). Designing and conducting focus group interviews. Retrieved from https://www.eiu.edu/ihec/Krueger-FocusGroupInterviews.pdf

Lawson, G., \& Myers, J. E. (2011). Wellness, professional quality of life, and careersustaining behaviors: What keeps us well? Journal of Counseling \& Development, 201(89), 163-172.

Martin, A. J., \& Marsh, H. W. (2006). Academic resilience and its psychological and educational correlates: A construct validity approach. Psychology in the Schools, 43(3), 267-281. https://doi.org/10.1002/pits.20149

Mitchell, J., Vella-Brodrick, D., \& Klein, B. (2010). Positive psychology and the internet: A mental health opportunity. E-Journal of Applied Psychology, 6(2), 30-41. https://doi.org/10.7790/ejap.v6i2.230

Mohd Tajudin, N., \& Rohany, N. (2014). Profesionalisme dalam kaunseling dan cabaran masa kini di Malaysia. Kuala Lumpur: Dewan Bahasa dan Pustaka.

Neenan, M. (2009). Developing resilience: A cognitive behavioural approach. Routledge.

Nor Ezdianie, O. (2020). Resiliensi dan keperluan kaunseling dalam kalangan pelajar bidang perhubungan menolong di universiti awam Terengganu. Unpublished doctoral dissertation, Universiti Teknologi Malaysia.

Norris, F. H. (2010). Behavioral science perspectives on resilience. CARRI Research Report 10. Retrieved from https://s31207.pcdn.co/wp-content/uploads/2019/09/ Behavioral-Science-Perspectives-on-Resilience.pdf 
Palma-Gómez, A., Herrero, R., Banõs, R., Garciá-Palacios, A., Castañeiras, C., Fernandez, G. L., Llull, D. M., Torres, L. C., Barranco, L. A., Cárdenas-Gómez, L., \& Botella, C. (2020). Efficacy of a self-applied online program to promote resilience and coping skills in university students in four Spanish-speaking countries: Study protocol for a randomized controlled trial. BMC Psychiatry, 20(1), 1-15. https://doi.org/10.1186/s12888-020-02536-w

Pearcey, P. A., \& Elliott, B. E. (2004). Student impressions of clinical nursing. Nurse Education Today, 24(5), 382-387. https://doi.org/10.1016/j.nedt.2004.03.007

Pfeiffer, D. (2001). Academic and environmental stress among undergraduate and graduate college students: A literature review. Unpublished Master thesis, University of Wisconsin-Stout.

Rahat, E., \& Ilhan, T. (2016). Coping styles, social support, relational self-construal, and resilience in predicting students' adjustment to university life. Educational Sciences: Theory \& Practice, 16(1), 187-208. https://doi.org/10.12738/estp .2016.1.0058

Resnick, B. A., \& Inguito, P. L. (2011). The resilience scale: Psychometric properties and clinical applicability in older adults. Archives of Psychiatric Nursing, 25(1), 11-20. https://doi.org/10.1016/j.apnu.2010.05.001

Richardson, G. E. (2002). The metatheory of resilience and resiliency. Journal of Clinical Psychology, 58(3), 307-321. https://doi.org/10.1002/jclp.10020

Shamzaeffa, S., \& Hong, K. T. C. (2016). Hubungan antara tahap kesihatan mental dan prestasi pelajar Sarjana Muda: Satu kajian di Universiti Utara Malaysia. Jurnal Sains Kesihatan Malaysia, 14(1), 11-16. http://ejournal.ukm.my/jskm/article/ view/12264/3884

Sherina, M. S., Lekhraj, R., \& Nadarajan, K. (2003). Prevalence of emotional disorders among medical students in a Malaysian university. Asia Pacific Family Medicine, 2, 213-217.

Skovholt, T. M., \& Ronnestad, M. H. (2003). Struggles og the novice counselor and therapist. Journal of Career Development, 30(1), 45-58. https://doi.org/10 $.1177 / 0022167805280266$

Skovholt, T. M., \& Trotter-Mathison, M. (2016). The resilient practitioner: Burnout and compassion fatigue prevention and self-care strategies for helping professions (3rd ed.). Routledge.

Sohana, A. H. (2019). Tahap kesihatan mental dalam kalangan pelajar institut pengajian tinggi: kajian literasi (Mental health level among student institute of higher education: literacy study). E- Prosiding Persidangan Antarabangsa Sains Sosial Dan Kemanusiaan 2019, 329-336.

Stamm, B. H. (2010). The concise manual for the professional quality of life scale. Retrieved from http://proqol.org/uploads/ProQOL_Concise_2ndEd_12-2010 .pdf

Suruhanjaya Komunikasi dan Multimedia Malaysia. (2018). Internet users non-users. Retrieved from https://www.mcmc.gov.my/skmmgovmy/media/General/pdf/ Internet-Users-Survey-2018-(Infographic).pdf 
Teddlie, C., \& Tashakkori, A. (2009). Foundations of mixed methods research: Integrating quatitative and qualitative approaches in the social and behavioral sciences. Sage Publications.

Thompson, E. H., Frick, M. H., \& Trice-Black, S. (2012). Counselor-in-training perceptions of supervision practices related to self-care and burnout. The Professional Counselor, 1(3), 152-162. https://doi.org/10.15241/eht.1.3.152

Thompson, G., McBride, R. B., Hosford, C. C., \& Halaas, G. (2016). Resilience among medical students: The role of coping style and social support. Teaching and Learning in Medicine, 28(2), 174-182. https://doi.org/10.1080/10401334.2016. 1146611

Turner, M., Holdsworth, S., \& Scott-Young, C. M. (2017). Resilience at university: The development and testing of a new measure. Higher Education Research \& Development, 36(2), 386-400. https://doi.org/10.1080/07294360.2016.1185398

Turner, M., Scott-Young, C. M., \& Holdsworth, S. (2016). Bouncing back to move forward: Resilience of students in the built environment. Proceedings of the 32nd Annual ARCOM Conference, 1(September), 627-636.

Tyre, Y., Griffin, M., \& Simmons, R. T. (2016). Building resiliency in counselors in training for counselor educators. The Alabama Counseling Association Journal, 41(1), 25-44.

Uehara, T., Takeuchi, K., Kubota, F., Oshima, K., \& Ishikawa, O. (2010). Annual transition of major depressive episode in university students using a structured self-rating questionnaire. Asia-Pacific Psychiatry, 2(2), 99-104.

Wang, J. (2009). A study of resiliency characteristics in the adjustment of international graduate students at American universities. Journal of Studies in International Education, 13(1), 22-45. https://doi.org/10.1177/1028315307308139

Yatimah, S., \& Mohd Tajudin, N. (2008). Teori kaunseling Al-Ghazali. Batu Caves, Selangor: PTS Islamika. 